\title{
Thevetia peruviana (Pers.) K. Schum. Potential Antifungal Agent Against Mycosphaerella fijiensis Morelet, Fungi Responsible of Black Leaf Streak Disease (BLSD) of Plantain (Musa spp)
}

\author{
Jules Patrice Ngoh Dooh (Corresponding author) \\ Department of Biological Sciences, Faculty of Sciences, University of Maroua, Cameroon, \\ BP 814, E-mail: ndjuliopat@yahoo.fr
}

Josué Ngando Essoh

Laboratory of Phytopathology of CARBAP, Njombe, Littoral-Cameroon

Serge Bertrand Mboussi

University of Douala, Laboratory of Plant Biology, PO Box 2701

\begin{abstract}
Alain Heu
Higher Technical Teacher's Training College, Department of Agriculture and Agropastoral Po Box 886 Ebolowa
\end{abstract}

William Norbert Kuate Tueguem

Laboratory of Biotechnologies, Phytopathology and Microbiology Unit, University of Yaounde I, PO Box, 812, Cameroon

Dieudonne Amayana

Laboratory of Phytopathology, IRAD of Ekona, South west Cameroon

Oscar Nguidjo

Laboratory of Phytopathology of CARBAP, Njombe, Littoral-Cameroon 


\author{
Richard Dongmo \\ Laboratory of Phytopathology of CARBAP, Njombe, Littoral-Cameroon
}

Kaze Fofe

Laboratory of Biotechnologies, Phytopathology and Microbiology Unit, University of Yaounde I, PO Box, 812, Cameroon

\begin{abstract}
Paul Martial Tene Tayo
Laboratory of Phytoprotection and Plant Valorization, Biotechnology Center, University of Yaoundé I P.O. Box 3851, Messa, Yaoundé Cameroon and Department of Biochemistry, University of Yaound I, Cameroon
\end{abstract}

Zachee Ambang

Laboratory of Biotechnologies, Phytopathology and Microbiology Unit, University of Yaounde I, PO Box, 812, Cameroon

Received: March 6, 2021 Accepted: April 21, 2021 Published: April 22, 2021

doi:10.5296/jas.v9i2.18553 URL: https://doi.org/10.5296/jas.v9i2.18553

\begin{abstract}
Alternatives to synthetic chemicals are undertaken against phytopathogens. The aim of this work is to evaluate the effect of seed extracts of Thevetia peruviana (Pers.) K. Schum. on Mycosphaerella fijiensis Morelet, fungus responsible for banana black leaf streak disease. Five extracts of $T$. peruviana, hexane extract (HE), ethyl acetate extract (EAE), acetone extract (AcE), methanol extract (ME) and aqueous extract (AqE), and a fungicide, Azoxystrobin were used. GC-MS of acetone extract was performed. Fifty (50) strains of M. fijiensis per sampling site were tested. Three concentrations of extracts 6.25 (C1), $12.5(\mathrm{C} 2)$, and $25(\mathrm{C} 3) \mu \mathrm{l} / \mathrm{ml}$, a negative control $(0 \mu \mathrm{l} / \mathrm{ml})$ and $10 \mathrm{ppm}$ of azoxystrobin were used for the tests. The MIC 50 and $\mathrm{MIC}_{90}$ were determined. GC-MS showed chemical compounds with different molecular height such as acids, sugars, and esters. AcE and AqE significantly reduced M. fijiensis germ tube growth at $\mathrm{C} 2$ and $\mathrm{C} 3$ concentrations and with inhibition percentage respectively ranged of $60-90 \%$ and $40-80 \%$. The growth levels of the germ tubes were above the strobilurin resistance threshold at Njombe and peasant plantation, ranging from $77.9 \%$ to $92.3 \%$. AcE showed the same or superior efficacy as the fungicide used on conidial germination at all tested
\end{abstract}


concentrations. The $\mathrm{MIC}_{50}$ totally reducing mycelial growth and conidial germination was 6.25 $\mu \mathrm{l} / \mathrm{ml}$. $T$. peruviana seeds extracts can be exploited in integrated pests management against $M$. fijiensis.

Keywords: Thevetia peruviana, Mycosphaerella fijiensis, extracts, GC-MS, Inhibition, conidia, germ tube

\section{Introduction}

Fungi are responsible for almpost $60 \%$ of crop diseases (Lepoivre, 2003). Their fructifications are the source of primary inoculum in farms. In Cameroon, Mycosphaerella fijiensis Morelet, a fungus belonging to Ascomycetes is responsible for the black leaf streak disease (BLSD)of plantain and sweet banana (Musa sp). Indeed, banana, which is ranked fourth among agricultural products after rice, wheat and maize, is the most popular fruit on the planet (Lescot, 2006; Lassoudière 2010). This very important sector for Cameroon (first African banana producer), contributes approximately $7 \%$ of primary GDP (Gross Domestic Product) and is the second largest national employer after the government and the second largest source of income after timber (Mouliom et al., 1997; Ngando et al., 2006). However, in most banana production areas, black leaf streak disease is the greatest threat (De Lapeyre et al., 2010). This disease caused by $M$. fijiensis affects the photosynthesis of bananas through partial or total drying of the foliar system of the plant (Mourichon, 2003). This results in yield losses of up to $100 \%$ (Hermento et al., 2010), the reduction of the green lifespan of fruits, making their transport and conservation problematic (Churchill, 2011).

During dry periods, conidial infection may be a very beneficial form of survival for $M$. fijiensis, with the understanding that ascospore infestation is less during these periods (Jacome and Schuh, 1992). Despite much less conidial production, they can cause disease as effectively as ascospores (Stover, 1980; Foure and Moreau, 1992; Jones 2009; Ngando et al., 2015).

More than $30 \%$ of the production of banana devoted for export are to the control of losses due to BLSD over the last 25 years which ranks $M$. fijiensis first among major agricultural pathogens (Abadie et al., 1999; Fullerton, 1994; De Lapeyre et al., 2009; Churchill, 2011).

Several control methods are used against this phytopathogen to reduce its effects on crops. The control of these parasites is accomplished only at the cost of frequent phytosanitary interventions. Farming practices that aim to reduce inoculum potential in the field by eliminating necrotic leaves and turning them upside down against the soil (Abadie et al., 1999; Mourichon, 2003). The development of resistant plants against this disease. However, this method is considered expensive and very long for farmers. In addition, fungi populations with a high level of genetic variability are difficult to control, and they can resist any control measure (El Hadrami, 2000). Some crops like bananas do not have resistant varieties, only chemical control methods are available for the farmer (Marin et al., 2003). Chemical control based mainly on the use of synthetic pesticides is the most effective method. This method unfortunately has consequences on the environment, micro-fauna, micro-flora, and human health because of the massive and inappropriate use of these fungicides. In addition, it is 
expensive, and it causes the emergence of resistant strains because of the misuse of these chemical pesticides. This phenomenon of resistance to systemic fungicides has become a crucial problem for banana plantations in Cameroon (Lepoivre, 2003; Ngando et al., 2006; El Guilli et al., 2009) and leads to the return to the use of contact fungicides. However, with contact fungicides, the number of sprays per week increase, which is more expensive.

Awareness of the environmental cost of these practices and consumers' fears of the danger that pesticide residues accumulated in plant and fish products may pose to human health are giving rise to a growing interest in other alternatives of control, more efficient and more environmentally friendly.

Among the alternatives, there is biological control which makes use of biological agents and their substances (antagonistic microorganisms) on one hand and the use of plant extracts on the other hand. In the context of integrated pest management, toxic and biodegradable molecules of plant and microbial origin are essential for reducing the harmful effects of plant parasites.

Many plants have been reported in the literature to have pesticidal properties against many plant parasites (Bautista-Banos, 2000; Kassi et al., 2014). The seeds, leaves, fruits and roots of yellow Oleander (Thevetia peruviana) are considered as potential sources of active biological compounds for insecticides (Reed et al., 1982; Ambang et al., 2005), rodenticides (Oji and Okafor, 2000). fungicides (Gata-Goncalves et al., 2003; Ambang et al., 2011; Ngoh Dooh et al., 2014b; Ngoh Dooh et al., 2015), virucides (Tewtrakul et al., 2002) and bactericides (Saxena and Jain, 1990). The general objective of this work is to evaluate the antifungal potential of extracts of Thevetia peruviana against $M$. fijiensis, agent responsible for black leaf streak disease.

\section{Material and Methods}

\subsection{Chemical Material}

The chemical material consisted of the active ingredient of Bankit, azoxystrobin, obtained from CARBAP.

\subsection{Obtention of M. fijiensis Conidia}

Fifty (50) banana plants, spatially representative of the identified plantation area of the Cavendish AAA variety (dessert banana) in the industrial zone and of the AAB (plantain) plantain subgroup in the peasant zone (Table I), showing typical symptoms of the disease Black streak disease were randomly selected from each zone's plantation. Leaf fragments with stage 2 and stage 3 lesions were collected, wrapped in plastics and transported to the laboratory. Sampling was done on young leaves of the plant not bearing fruit. Hooks were used in areas where banana leaves were very high (Ngando et al., 2006, Nguepjop, 2011, Ngando et al., 2015). 
Table I: sampling sites (PHP: Upper Penja Plantation; CDC: Cameroon Development Corporation); Peasant: Mbome)

\begin{tabular}{cll}
\hline Agro-ecological Region & Plantations & Sector \\
\hline \multirow{2}{*}{ Littoral } & Peasant & Mbome \\
& PHP & Njombe \\
\hline South West & CDC & Mussaka \\
\hline
\end{tabular}

\subsection{Obtention of the Extracts}

The fruits were harvested from different parts of Yaounde City and then crushed with a stone. The seeds obtained were dried at room temperature in the Phytopathology laboratory of the Department of Plant Biology of the University of Yaounde I for 3 to 4 weeks. The seeds were crushed using a hand-mill of brand "Victoria". The resulting powder was loaded into cartridges and mounted on the soxhlet. The various extraction solvents hexane (HE), ethyl acetate (EAE), acetone (AcE) and methanol (ME) were each put in turn $48 \mathrm{~h}$ to $72 \mathrm{~h}$ (Negrette et al., 1987). The product obtained was concentrated in a rotary evaporator at the evaporation temperature of the corresponding solvent to eliminate the latter. The extract obtained was stored in the refrigerator at $4{ }^{\circ} \mathrm{C}$ until use. After this process, the residue was stored and mounted in the apparatus with another solvent.

The aqueous extract (AqE) was obtained by maceration of the powder in sterile distilled water for at least 12 hours (Stoll, 1994). The powder was put into a muslin cloth and soaked in a volume of sterile distilled water necessary to obtain the concentration of the desired stock solution ( $36 \mathrm{~g}$ in $72 \mathrm{ml}$ of water). The extraction yield of each extract was calculated.

Screening of all these extracts was done previously (Table 2).

Table 2. Occurrence of natural products of each respective extract (Ngoh Dooh et al. 2014a).

\begin{tabular}{|c|c|c|c|c|c|}
\hline Products & Hexane & Ethyl acetate & Acetone & Methanol & Aqueous \\
\hline Essential oils & $\mathrm{T}$ & - & + & + & + \\
\hline Saponifiable oils & + & + & + & _ & + \\
\hline Coumarines & _- & + & + & + & + \\
\hline Alkaloids & _ & _ & _ & + & + \\
\hline Sterols & - & + & + & + & +++ \\
\hline Terpenoids & - & - & - & $\mathrm{T}$ & - \\
\hline Flavonoids & - & - & - & - & - \\
\hline Anthraquinones & _ & _- & _- & _- & + \\
\hline Catechic tannins & - & - & - & + & - \\
\hline Gallic tannins & _ & _- & _- & _- & _ \\
\hline Saponins & _ & _ & + & + & + \\
\hline Anthocyanes & - & + & - & + & - \\
\hline Steroic glycosides & _ & $\mathrm{T}$ & + & + & + \\
\hline $\begin{array}{l}\text { Triterpnoid } \\
\text { glycosides }\end{array}$ & - & - & - & $\mathrm{T}$ & - \\
\hline Free sugars & - & _- & $\mathrm{T}$ & $\mathrm{T}$ & +++ \\
\hline Phenols & & & & $\mathrm{T}$ & - \\
\hline
\end{tabular}

- Absence of the products, + presence, +++ abundant presence, $\mathrm{T}$ presence in traces. 


\subsection{Preparation of Concentration of Extracts}

A stock solution of $500 \mu \mathrm{l} / \mathrm{ml}$ concentration was prepared by mixing $1 \mathrm{ml}$ of the extract, 0.25 $\mathrm{ml}$ of solvent and $0.75 \mathrm{ml}$ of distilled water giving an initial volume of $2 \mathrm{ml}$.

From the stock solution, the concentrations of $6.25,12.5$ and $25 \mu 1 / \mathrm{ml}$ were obtained by taking $0.25 \mathrm{ml}, 0.5 \mathrm{ml}$ and $1 \mathrm{ml}$ respectively from the stock solution and adding them to $19.75 \mathrm{ml}, 19.5 \mathrm{ml}$ and $19 \mathrm{ml}$ of culture medium, water agar, i.e., a final volume of $20 \mathrm{ml}$. (Gata-Gonçalves, 2001). The concentrations of the aqueous extract, 6.25, 12.5 and $25 \mathrm{mg} / \mathrm{ml}$, were obtained by the same method from a stock solution of $500 \mathrm{mg} / \mathrm{ml}$.

\subsection{Dilution of Azoxystrobin}

A positive control made of the active ingredient of bankit, a fungicide commonly used against leaf streak disease, azoxystrobin, was performed. The required dose is that recommended by the Fungicide Resistance Action Committee (FRAC), International Group of National Associations of Agrochemical Manufacturers for laboratory tests, or 10 ppm (Essis et al., 2010; Ngueujop, 2011; Ngando , et al., 2015). A 10000-ppm stock solution was prepared by mixing $50 \mathrm{mg}$ of active ingredient in $5 \mathrm{ml}$ of methanol $(\mathrm{MeOH})$ in a tube and all was homogenized in vortex (VMR). Then $100 \mu \mathrm{l}$ was taken from the stock solution and added to $99.9 \mathrm{ml}$ of water agar medium.

An antibiotic, Chloramphenicol (200mg/l), was added in the medium to prevent bacterial contamination of water agar medium.

The volumes obtained were poured aseptically into Petri dishes of $90 \mathrm{~mm}$ of diameter under a laminar flow hood the day before the different tests.

\subsection{Assessment of the Effects of the Extracts on the Growth of the Germ Tube of M. Fijiensis}

A well-insulated lesion, susceptible of bearing conidia on its surface is cut with a scalpel from each piece of leaf and following its borders to avoid taking several lesions at the same time.The lower surface of the lesion was applied in the media containingthe different treatments so as to leave its footprint. Each lesion was first applied to a test control medium to ensure the effectiveness of the sporulation and then in the treatments. One lesion served as a source of inoculum for the different treatments and for a concentration in the context of this monitoring with the conidia method for each site. The Petri dishes were incubated for 48 hours in the culture room at $25^{\circ} \mathrm{C}$ and in continuous light.

After 48 hours, observations were made on 50 strains of $M$. fijiensis for both cultures. The marks of the lesions in the quadrille and numbered Petri dishes were easily visible under the microscope. Readings were made following the number of the lesion using a micrometer (Mouliom et al., 1997; Essis et al., 2010; Nguepjop, 2011).

The first measured criterion is the length $(\mu \mathrm{m})$ of the inhibited germ tubes which reflects the action of the extracts and fungicide on medium. The measurement of the length of the germ tube was done from the last septum or from the insertion base of the conidial germ tube to its longest end. Three conidia were measured by repetition and the average was selected. 
For each site, and for each concentration, an average length of the germ tubes of 50 conidia on control (Lc) and on medium amended with extracts or fungicide (Lf) were calculated. The percentage inhibition of germ tube growth (Ia) was calculated using the formula:

$$
I a=\frac{L c-L f}{L c} * 100(\text { Ngando et al.,2006; Essis et al., 2010) }
$$

The growth rate (GT) was subsequently evaluated according to the formula GR=100 - Ia, to assess the resistance threshold.

The laboratory threshold for reporting resistance was set for Strobilurins (Bankit) at $75 \%$ of control (25\% sensitivity) according to FRAC recommendations (Brent and Hollomon, 1998; Knight et al., 2002; Essis et al., 2010).

\subsection{Assessment of the Effects of Extracts on the Germination of Conidia}

The different concentrations that were used in the growth test were maintained.

The Petri dishes were incubated in continuous light for $48 \mathrm{~h}$. About 25 to 30 conidia were counted, some lesions did not 'spit' a lot of conidia. The laboratory threshold for declaring resistance was set at $80 \%$, i.e., $20 \%$ of the sensitivity (Du Pont, 1983; Smith et al., 1991; Essis et al., 2010).

A spore was considered germinated if the length of the germ tube was equal to or greater than the diameter of the spore.

The percentages of inhibition were then evaluated according to the following formula:

$\mathrm{PI}=(\mathrm{A}-\mathrm{B}) / \mathrm{A} X 100 \quad$ (Leroux et al.,1978).

Avec: $\quad \mathrm{PI}=$ percentage of inhibition; $\mathrm{A}=$ number of spores of germinated in the control medium; $\mathrm{B}=$ number of spores germinated in the presence of the extract or fungicide.

\subsection{Acetone Extract Analysis (GC-MS)}

The acetone extract which exhibiting the highest percentage of inhibition against $M$. fijiensis was analysed by capillary gas chromatography followed by mass spectrometry (GC-MS), using an Autosystem XL gas chromatograph (Agilent GC 7890A) with a vaporisation injector in split mode (1:50) interfaced to a Turbomass Perkin-Elmer mass-spectrometer (Agilent $5975 \mathrm{C}$ TAD VL MSD). The analytical parameters were helium as carrier gas with the column flow rate of $1.21 \mathrm{ml} / \mathrm{min}$. The oven temperature program was $40{ }^{\circ} \mathrm{C}$ for $3 \mathrm{~min}$, then increased at $5{ }^{\circ} \mathrm{C} / \mathrm{min}$ to $180{ }^{\circ} \mathrm{C}$, followed by $15^{\circ} \mathrm{C} / \mathrm{min}$ to $240{ }^{\circ} \mathrm{C}$ and finally to $300{ }^{\circ} \mathrm{C}$ at 10 ${ }^{\circ} \mathrm{C} / \mathrm{min}$ fractions (isothermal $15 \mathrm{~min}$ ). A fused-silica capillary column, $30 \times 25 \mathrm{~mm}$ i.d. $30 \times 32$ mm (DB-1; 100\% di- 150 99. methylpolysiloxane) was used. The ion source and transfer line temperatures were maintained at 200 and $280{ }^{\circ} \mathrm{C}$, respectively. Electron ionisation mass spectra in the range 40-500 Da were recorded at $70 \mathrm{eV}$ electron energy. The scan time was 1 $\mathrm{ms}$, the multiplier potential $430 \mathrm{~V}$ and the source pressure 10 Torr. A computer recorded all data and compounds were identified by comparison with the Wiley's and Nist libraries spectral data bank. The fraction previously evaporated and re-suspended in dichloromethane 
was analysed twice ( $1 \mathrm{ml}$; "hot-needle") and, for semi-quantitative purposes, the average percentage composition was computed from peak areas normalised without using correction factors.

\subsection{Evaluation of Minimum Inhibitory Concentrations (MIC50 and MIC90)}

From the linear regression equation between the Neperian logarithms of the abscissa concentrations and the ordinate inhibition percentages, the concentrations reducing growth by 50\% ( $\mathrm{MIC}_{50}$ ) and $90 \%$ (MIC90) were determined (Dohou et al., 2004).

Only data from germ tube growth were used to calculate MICs, as recommended by the FRAC.

\subsection{Statistical Analysis}

Statistical analysis of the in vitro observation data and study of correlations was done using the SPSS 16.0 software. The. Principal component analyzes (PCA) were performed using the XLSTAT 2007.8.04 software to classify the different extracts with respect to azoxystrobin. The Student Newman Keuls and Duncan tests at the 5\% threshold allowed the comparison of the different averages when the differences were significant.

\section{Results}

\subsection{Acetone Extract Chromatographic and Mains Constituents Found}

More than 10 peaks were observed in the chromatographic profil of acetone extract (Figure 1). Peak retention time varied from 2.71 to $7.19 \mathrm{mn}$ and peak height ranged from 172006 to 1579559. 


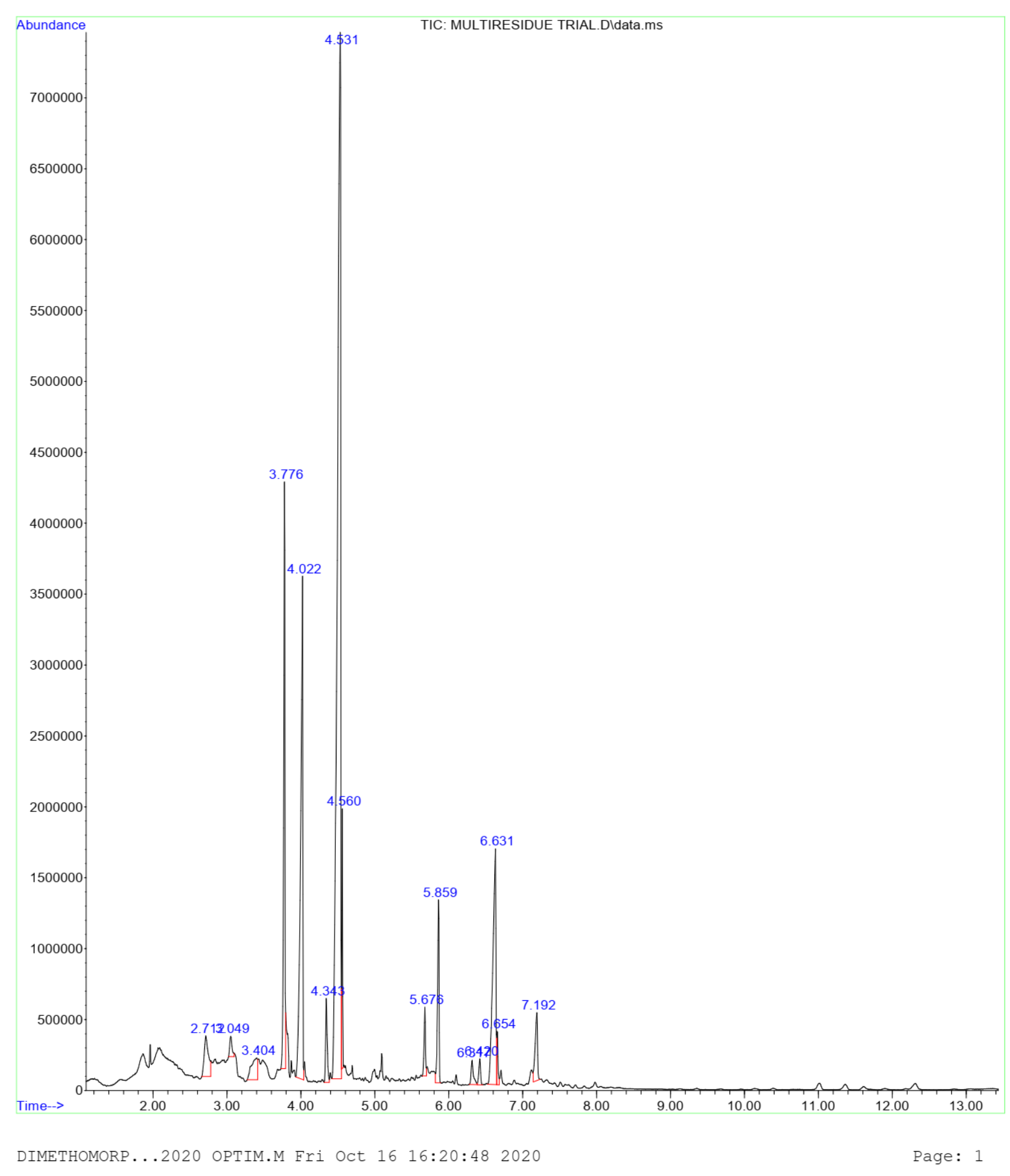

Figure 1. GC-MS Chromatographic profil of acetone extract

Many compouds with different molecular weight were obtained from each peak (Table 2). Acid compounds such decanoid acid, tridecanoid acid and pentadecanoid acid were revealed. Sugar such as maltose, Ethyl. beta. -d-riboside were obtained. Major compounds were acids (Table 2). Some compounds were not identified. 
Table 2. Composition of the constituents found in the acetone extract after GC-MS

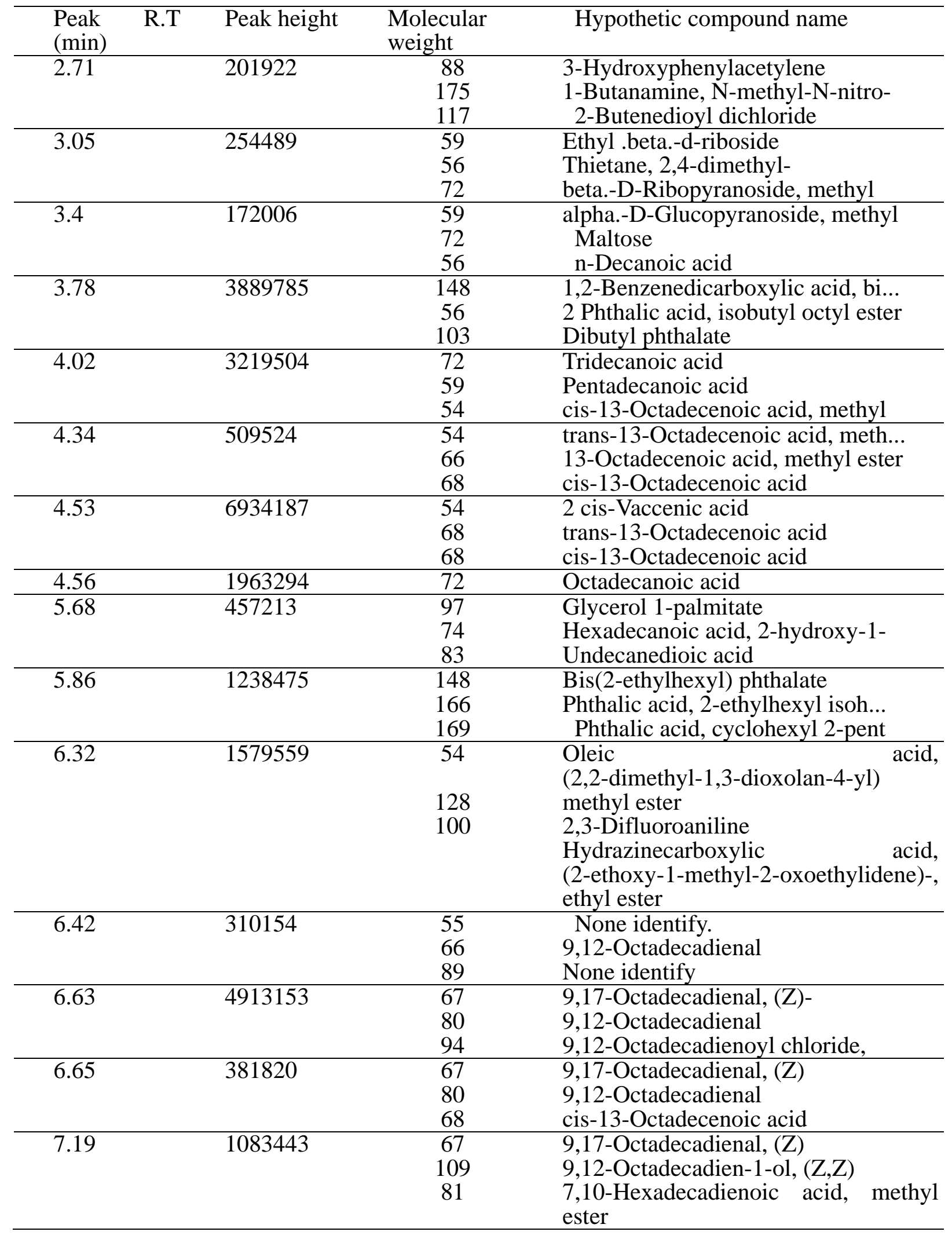




\section{Macrothink}

\subsection{Effects of Extracts on the Growth of Germ Tube of M. fijiensis Strains}

\subsubsection{The Effect of the HE Extract on the Growth of the Germ Tube of M. fijiensis Strains}

The HE extract had a very small effect on germ tube growth.No significant difference (P> 0.05)were observed between the differentconcentrationsapplied and in any of the three study. The highest inhibition percentages recorded were 18.8, 15.0 and $11.5 \%$, respectively at Njombe (PHP), Mussaka and Mbome at the highest concentration $\mathrm{C}_{3}$. The lowest inhibitions were obtained in the peasant plantation $\left(1.1\right.$ and $1.2 \%$ at $\mathrm{C}_{1}$ and $\mathrm{C}_{2}$ concentrations, respectively. Inhibition of germ tubes by the bankit was highest than that of $\mathrm{EH}$ extract.Highest percentage inhibitions recorded were 50.4, 86.3 and $93.4 \%$ respectively in Mussaka, PHP, peasant zone ((Figure 2).

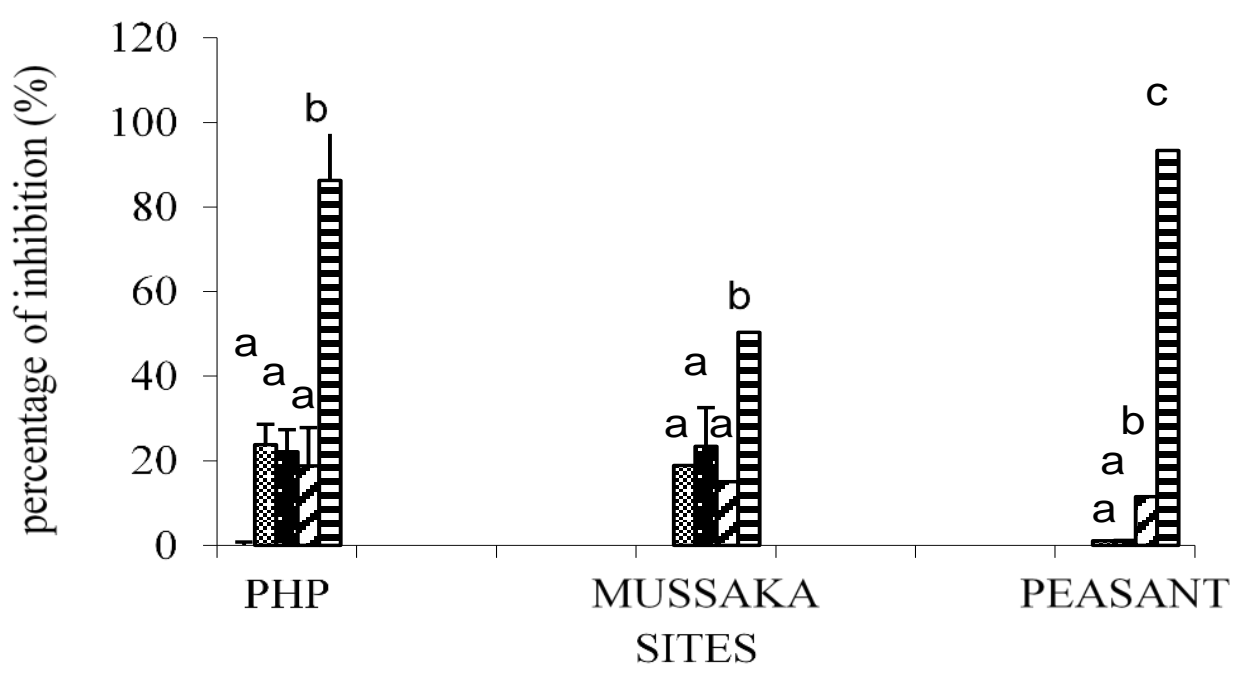

Figure. 2. Effect of HE on germ tube growth of M. fijiensis strains

For each site the assigned values of the same letter do not differ significantly according to the Duncan test at the $5 \%$ threshold

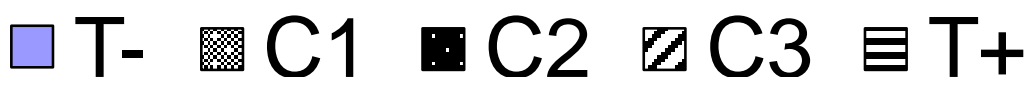

T- : $0 \mu \mathrm{l} / \mathrm{ml} ; \mathrm{C}_{1}: 6,25 \mu \mathrm{l} / \mathrm{ml} ; \mathrm{C}_{2}: 12,5 \mu \mathrm{l} / \mathrm{ml} ; \mathrm{C}_{3}: 25 \mu \mathrm{l} / \mathrm{ml} ; \mathrm{T}+: 10 \mathrm{ppm}$

\subsubsection{Effect of EAE on germ tube growth of $M$. fijiensis strains}

The EAE extract was shown to be less effective in inhibiting the elongation of the germ tube of $M$. fijiensis conidia. An increase in percent inhibition was revealed as a function of concentration with this extract. Thus, at Mussaka 9.0, 32.8 and 54.6\% inhibition, respectively of concentrations $\mathrm{C}_{1}, \mathrm{C}_{2}$ and $\mathrm{C}_{3}$ were obtained. The highest sensitivity of the conidia to this extract was found at the $\mathrm{C}_{3}$ dose with $48.8,54.6$ and 50.8\% inhibition, respectively at Njombe 


\section{Macrothink}

(PHP), Mussaka and the peasant zone. At Mussaka, this extract was more effective $(\mathrm{P}<0.05)$ than the bankit, at $\mathrm{C}_{3}$ concentration (Fig. 6).

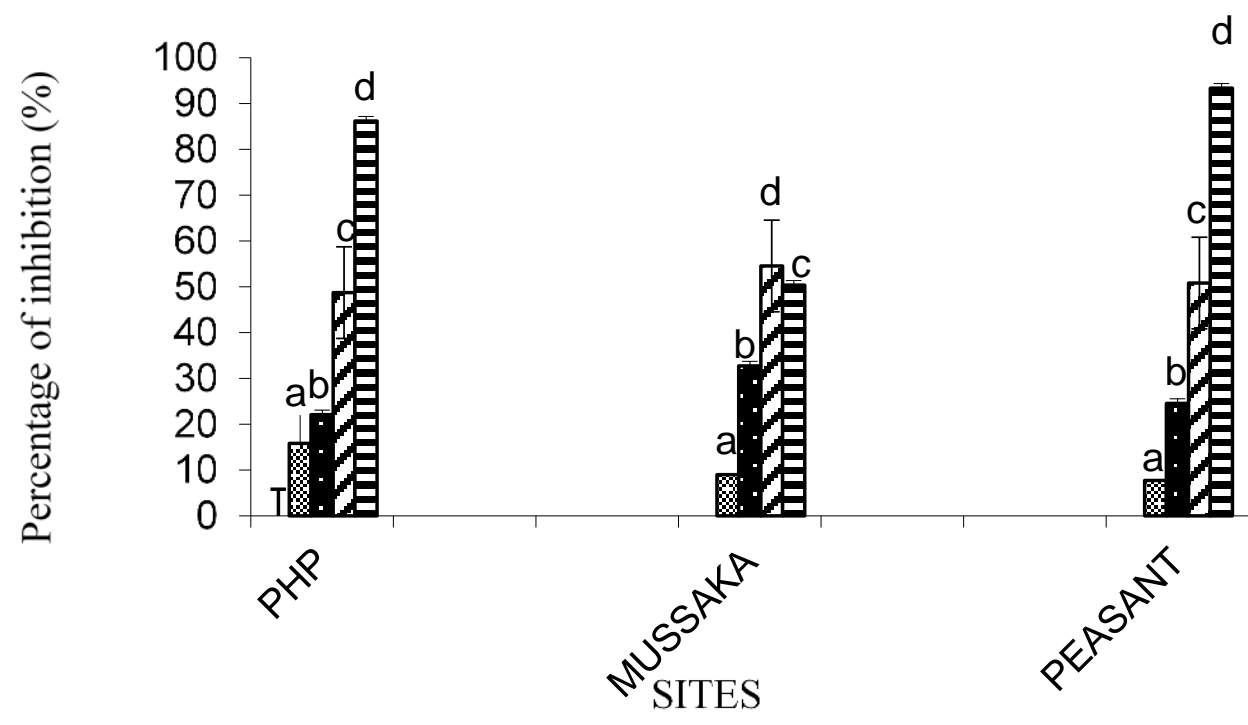

Figure 6. Effect of EAE on germ tube growth of M. fijiensis strains

For each site, the assigned values of the same letter do not differ significantly according to the Duncan test at $5 \%$ threshold.

\section{$\square \mathrm{T}-\square \mathrm{C} 1 \square \mathrm{C} 2 \square \mathrm{C} 3 \approx \mathrm{T}+$}

T- : $0 \mu \mathrm{l} / \mathrm{ml} ; \mathrm{C}_{1}: 6,25 \mu \mathrm{l} / \mathrm{ml} ; \mathrm{C}_{2}: 12,5 \mu \mathrm{l} / \mathrm{ml} ; \mathrm{C}_{3}: 25 \mu \mathrm{l} / \mathrm{ml} ; \mathrm{T}+: 10 \mathrm{ppm}$

\subsubsection{Effect of AcE on Germ Tube Growth of M. fijiensis Strains}

AcE was very effective in reducing the growth of the germ tube.Inhibition increased with concentrations in all areas.In the Njombe zone (PHP), 62.1, 84.2 and 95.8\% inhibition of germ tube growth were obtained with $\mathrm{C}_{1}, \mathrm{C}_{2}$ and $\mathrm{C}_{3}$ concentrations, respectively. In the peasant zone, inhibition percentages were $62.8,91.8$ and $97.8 \%$, respectively, at the three concentrations. The AcE extract were more sensitive to germ tube growth compared to the bankit. At Mussaka, all concentrations showed highest inhibition than azoxystrobin $(\mathrm{P}<0.05)$. In Njombe and Mbome, only, $\mathrm{C}_{2}$ and $\mathrm{C}_{3}$ concentrations inhibited germ tube than the bankit. However, no significant difference was observed between the bankit concentration and the $\mathrm{C}_{2}$ and $\mathrm{C}_{3}$ concentrations of $\mathrm{AcE}$ at $\mathrm{Mbome}(\mathrm{P}=0.36)$, (Fig.7).

All samples were very sensitive to AcE (Fig. 11c) as the lengths of the germ tube were very short. 


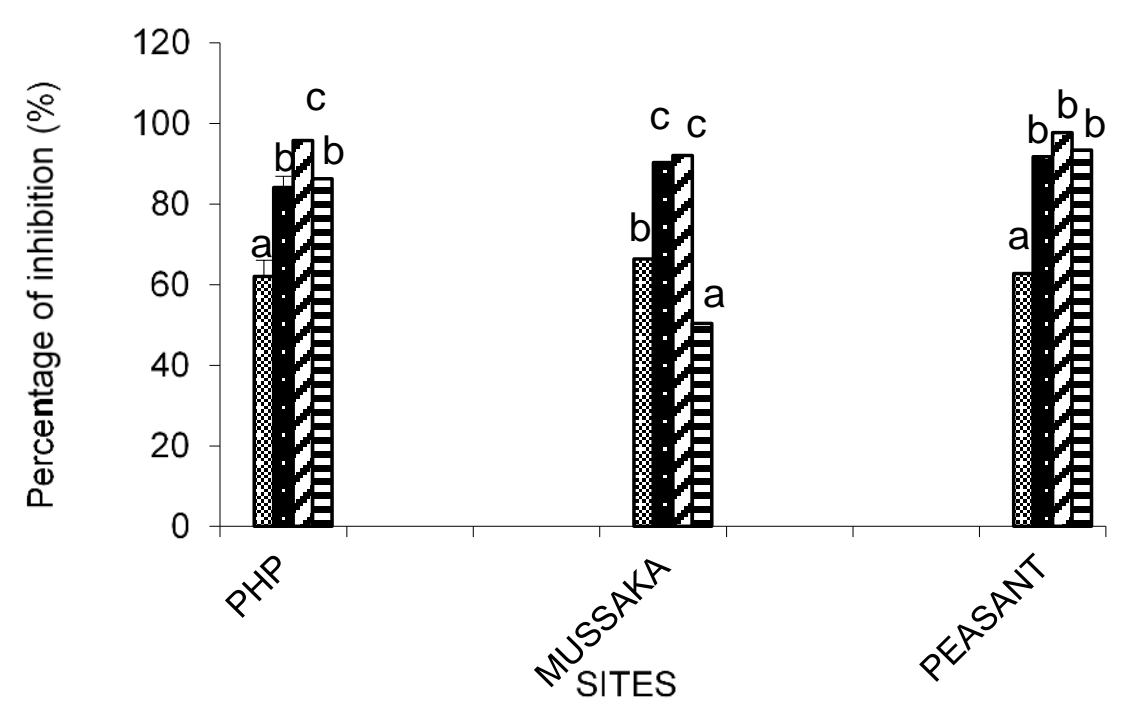

Figure 7. Effect of EAc on germ tube growth of M. fijiensis strains

For each site the assigned values of the same letter do not differ significantly according to the Duncan test at the $5 \%$ threshold

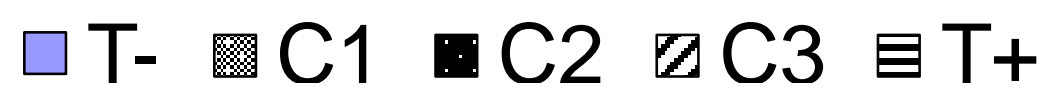

T- : $0 \mu \mathrm{l} / \mathrm{ml} ; \mathrm{C}_{1}: 6,25 \mu \mathrm{l} / \mathrm{ml} ; \mathrm{C}_{2}: 12,5 \mu \mathrm{l} / \mathrm{ml} ; \mathrm{C}_{3}: 25 \mu \mathrm{l} / \mathrm{ml} ; \mathrm{T}+: 10 \mathrm{ppm}$

\subsubsection{Effect of ME on Germ Tube Growth of M. Fijiensis Strains}

Strains from the peasant plantation showed resistance to the methanol extract. The inhibition percentages were $10.9,8.2$ and $25.1 \%$, respectively at $\mathrm{C}_{1}, \mathrm{C}_{2}$ and $\mathrm{C}_{3}$ concentrations. A sensitivity to the extract was obtained at the $\mathrm{C}_{3}$ concentration with samples from the two industrial zones, $45.8 \%$ in Njombe (PHP) and $43.5 \%$ in Mussaka (Fig.8). No concentration matched the effectiveness of azoxystrobin in the areas studied. The lowest inhibition percentages were obtained with the samples from the peasant zone $(\mathrm{P}>0.05)$. 


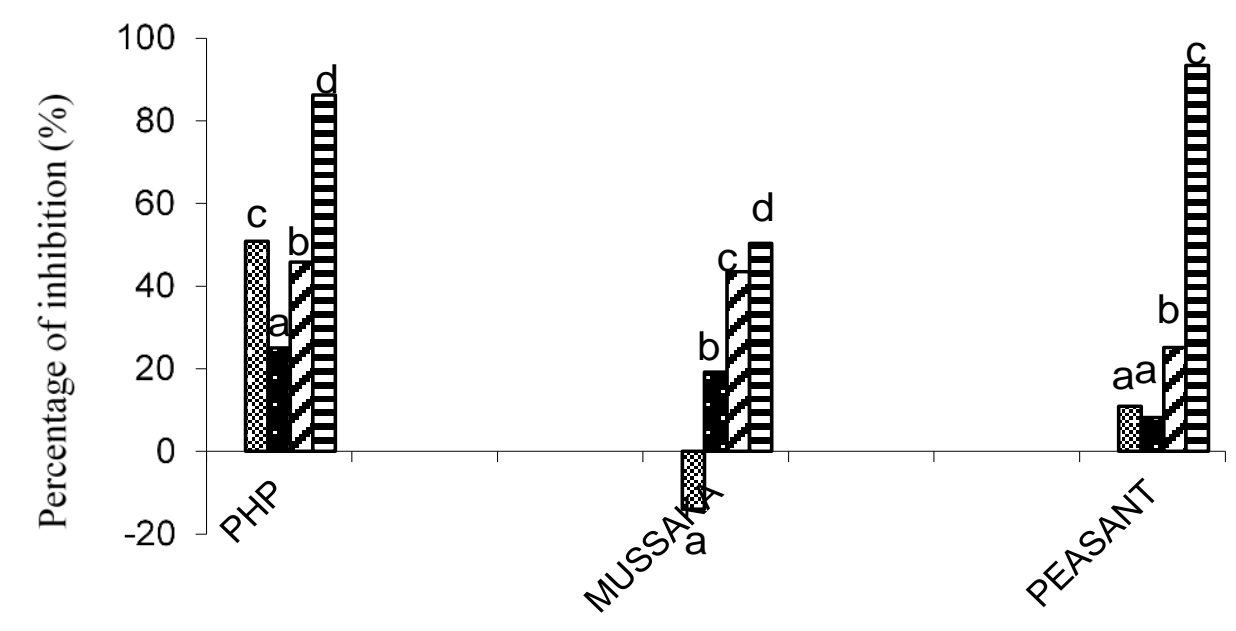

SITES

Figure 8. Effect of ME on germ tube growth of $M$. fijiensis strains

For each site, the assigned values of the same letter do not differ significantly according to the Duncan test at the $5 \%$ threshold

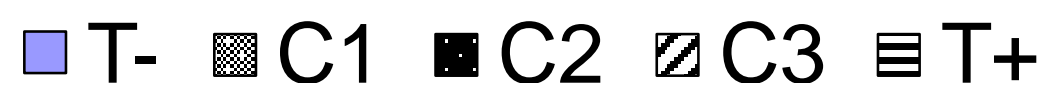

T- : $0 \mu \mathrm{l} / \mathrm{ml} ; \mathrm{C}_{1}: 6,25 \mu \mathrm{l} / \mathrm{ml} ; \mathrm{C}_{2}: 12,5 \mu \mathrm{l} / \mathrm{ml} ; \mathrm{C}_{3}: 25 \mu \mathrm{l} / \mathrm{ml}$; T+: $10 \mathrm{ppm}$

\subsubsection{Effect of AqE on Germ Tube Growth of M. fijiensis Strains}

The aqueous extract proved to be sensitive to the development of the germ tube length at all concentrations., the germ tubes growth was reduced compared to the control (Fig. 11b). In the industrial plantation of PHP at Njombe site, the inhibition rates of 40.0, 47.5 and $55.8 \%$ were obtained at different concentration, respectively. The sensitivity was very high with the samples from peasant plantation, the percentages of inhibition were 81.4 and $75 \%$ at $\mathrm{C}_{3}$ and $\mathrm{C}_{1}$ concentrations. At Mussaka, strains were sensitive at $\mathrm{C}_{2}$ and $\mathrm{C}_{3}$ concentrations than Bankit ( $\mathrm{P}<0.05$ ), the percentages of inhibition were 66.9 and $77.6 \%$ against $50.4 \%$ for azoxystrobin. No significant difference $(\mathrm{P}=0.114)$ was obtained at Mussaka between $\mathrm{C}_{1}$ and azoxystrobin concentrations (Fig 9). 


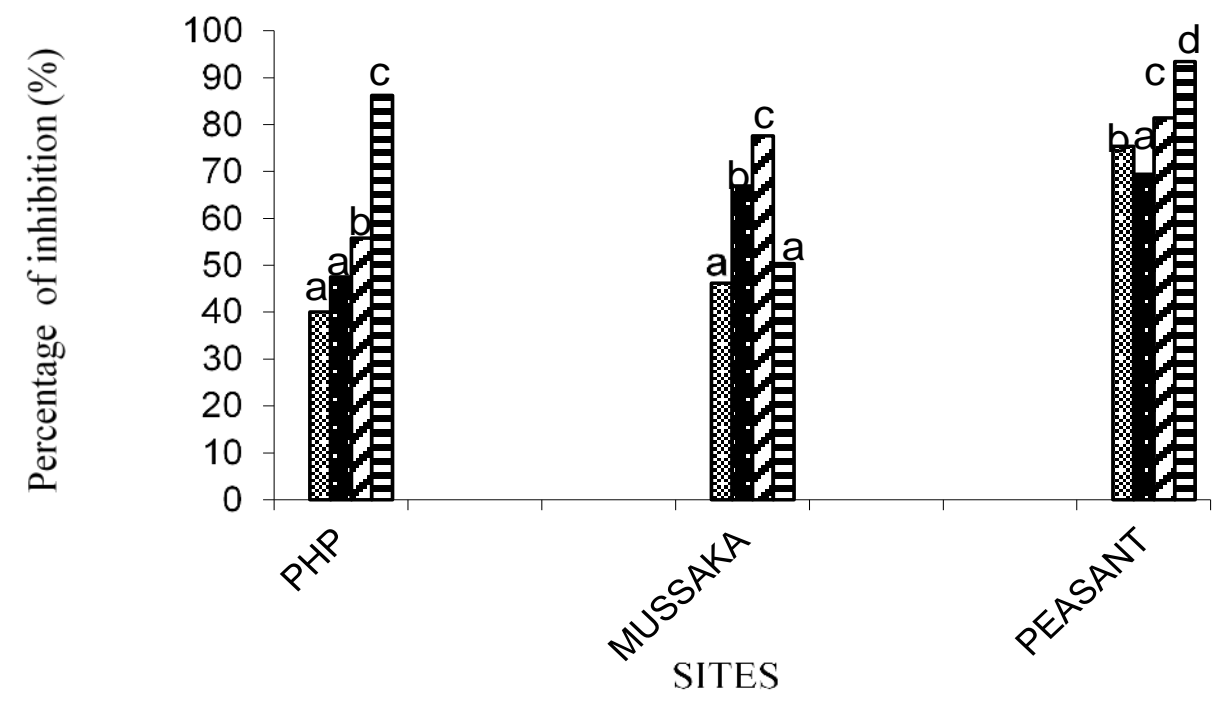

Figure 9. Effect of AqE on germ tube growth of M. fijiensis strains

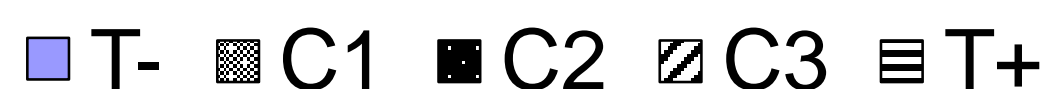

For each site the assigned values of the same letter do not differ significantly according to the Duncan test at the $5 \%$ threshold

T-: 0 mg/ml; $\mathrm{C}_{1}: 6,25 \mathrm{mg} / \mathrm{ml} ; \mathrm{C}_{2}: 12,5 \mathrm{mg} / \mathrm{ml} ; \mathrm{C}_{3}: 25 \mathrm{mg} / \mathrm{ml} ; \mathrm{T}+: 10 \mathrm{ppm}$

The probability correlation circle of $59.78 \%$ revealed four distinct groups. A group consisting of $\mathrm{HE}$ whose inhibition on germ tube growth was very low. The second group containing EAE, AcE and AqE, which showed an efficiency on germ tube growth. A third group consisting of ME which showed a moderate efficiency on the inhibition of germ tube growth of $M$. fijiensis and finally a group consisting of positive control T + (Fig. 10). 


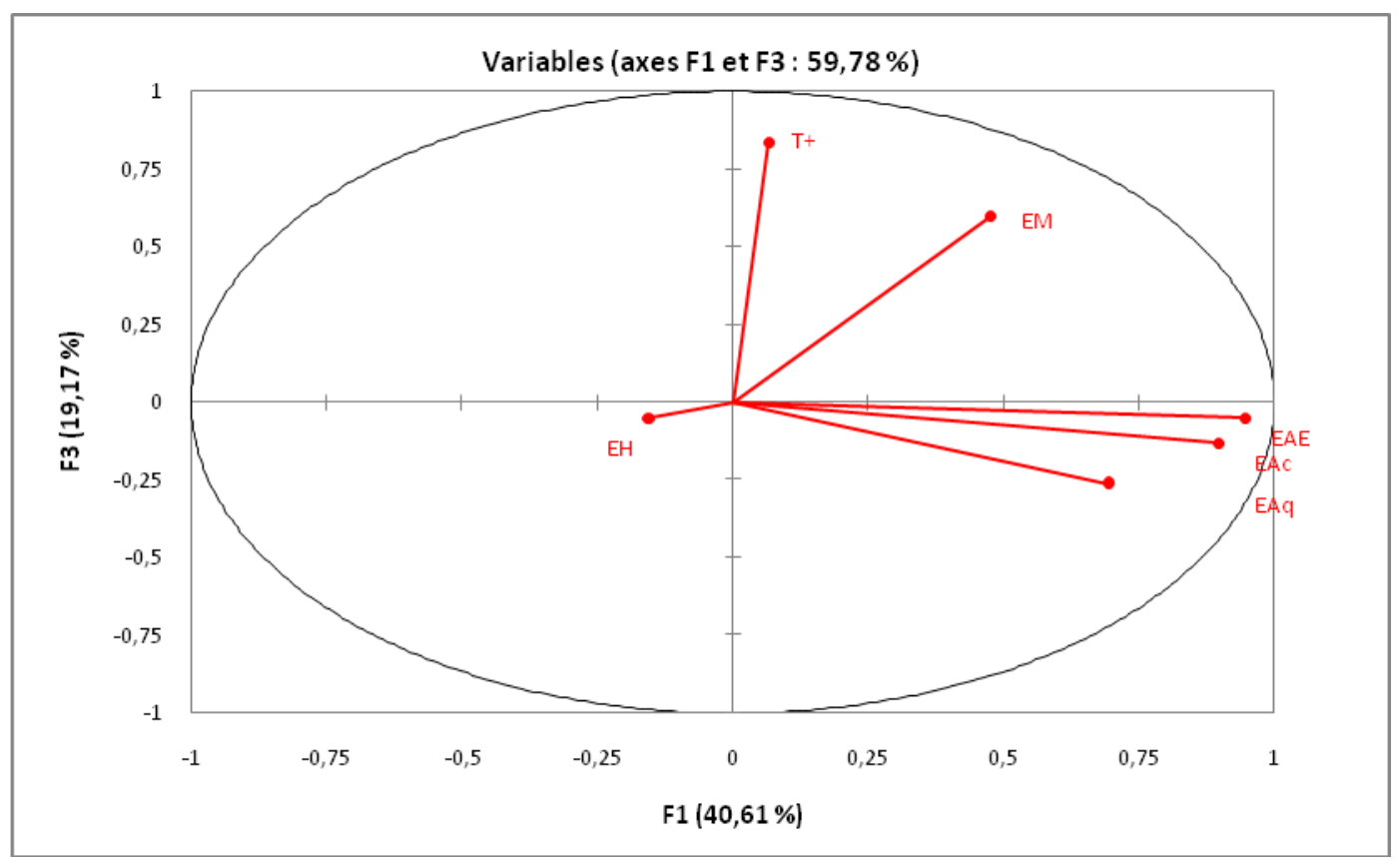

Figure 10. Mapping of extracts and fungicide effective on inhibition of germ tube growth of M. fijiensis conidia

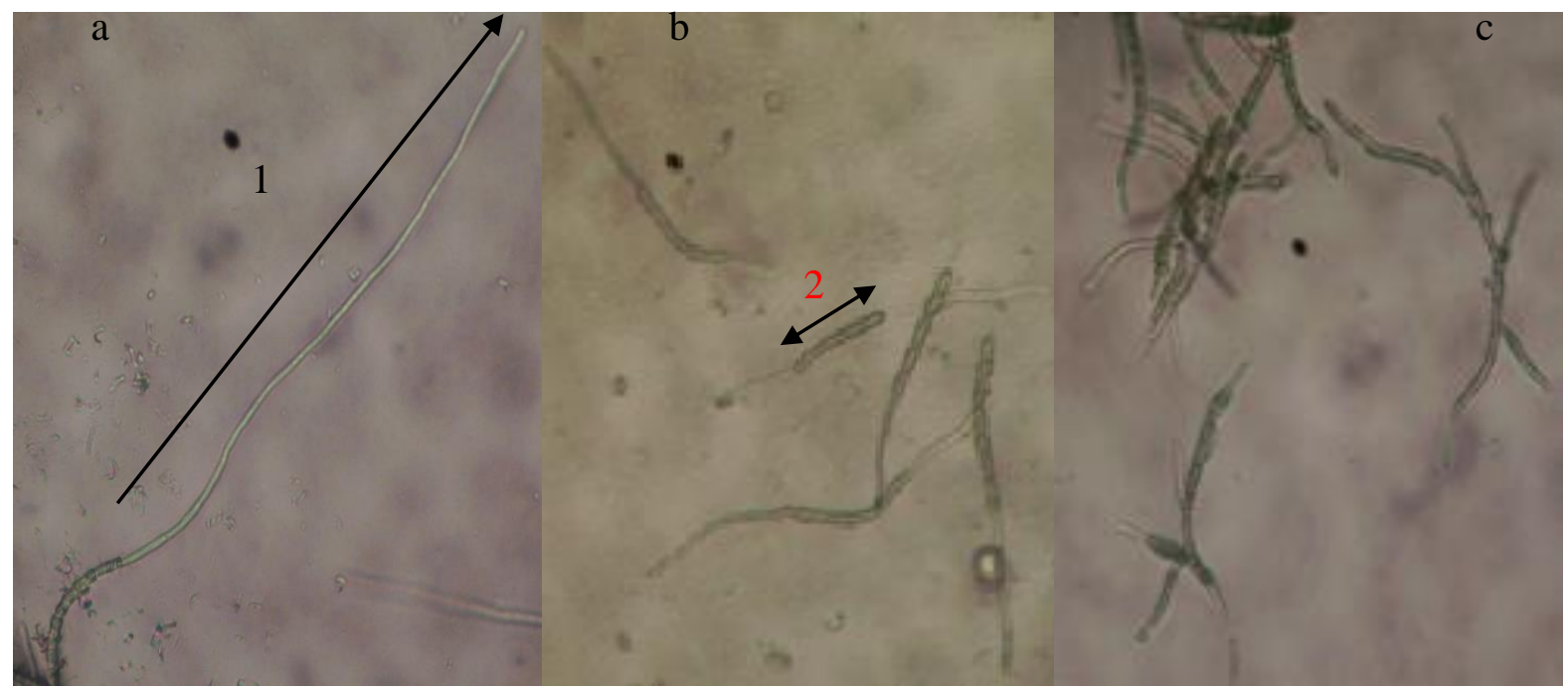

Figure 11. Measurement of the germ tube in the various media supplemented with extracts at the $\mathrm{C}_{3}$ dose: normal conidia on media, control (a). Conidia very sensitive on media with AqE (b) and AcE (c). 1 = germ tube; 2 = conidia

\subsection{Effect of Different Extracts and Azoxystrobin on the Germination of M. fijiensis Conidia}

The HE had no effect on the germination of the conidia of $M$. fijiensis. The percentages of inhibition ranged $0-0.5 \%, 0.2-0.6 \%$ and $0.5-8.6 \%$ respectively with samples of PHP, Mussaka and peasant plantation. No significant difference was obtained between treatment (P> $0.05 \%)$. The lowest value of the percentage inhibition of germination with the bankit was 
obtained in Mussaka, 38.6\% against $99.5 \%$ in the peasant zone. The germination rates obtained with this extract werelargely above the resistance threshold of $25 \%$ Strobilurins (Table 3).

The EAE extract was less effective on the germination of $M$. fijiensis conidia at all concentrations. With the samples from PHP, the percentages of inhibition obtained were 2.5, 2.5 and $1 \%$, respectively with the doses $\mathrm{C}_{1}, \mathrm{C}_{2}$ and $\mathrm{C}_{3}$. At Mussaka the percentages were ranged $0.2,2.5$ and $3.2 \%$. All inhibition percentages obtained with this extract were lower than those obtained with azoxystrobin (Table 3).

The AcE proved to be very effective against the germination of $M$. fijiensis conidia. In industrial plantations, only the concentration of $6.25 \mu \mathrm{l} / \mathrm{ml}$ gave low inhibition percentages, $8.1 \%$ and $38.5 \%$ in Njombeand Mussaka, respectively. The $\mathrm{C}_{2}$ and $\mathrm{C}_{3}$ concentrations were the most effective in these industrial zones, with $64.1 \%$ and $99 \%$ inhibition respectively at Njombe (PHP) against $85.4 \%$ and 96\%at Mussaka. The strains of these industrial zones showed a slight resistance to this extract compared to the samples from the peasant plantation where the percentages of inhibition were $54.8,97.8$ and $100 \%$ respectively at $\mathrm{C}_{1}, \mathrm{C}_{2}$ and $\mathrm{C}_{3}$ concentrations. In Njombe (PHP), the $\mathrm{C}_{3}$ dose induced $99 \%$ inhibition rate while the bankitrate was $81.8 \%(\mathrm{P}<0.05)$. The same result was obtained at Mussaka, the inhibition percentages obtained were significantly higher and significantly different from those obtained with the bankit (Table 3). However, in the peasant plantation, no significant difference was between concentration of extracts and bankit $(\mathrm{P}=0.335)$. Total inhibition was obtained with samples of peasant zone in the highest concentration, no conidial.

The ME extract was no sensitive to conidial germination. With the samples from the industrial plantation of Njombe (PHP), the inhibition percentages obtained were 17.8, 11.6 and $34.8 \%$, respectively at the three concentrations. In Mussaka the percentages were 0, 0.6 and $34.6 \%$ and $13.4,7.5$ and $9.1 \%$ in the peasant plantation respectively at $\mathrm{C}_{1}, \mathrm{C}_{2}$ and $\mathrm{C}_{3}$. Njombe (PHP) strains were slightly more sensitive to this extract than those of the other two sampling areas. In the three study areas, the bankit showed highest efficacy than this extract (P<0.05) (Table 3).

AqE was effective against germination of conidia from the peasant plantation and the Mussaka industrial area. At $\mathrm{C}_{2}$ and $\mathrm{C}_{3}$ there were 42.3 and $62 \%$ inhibition in Mussaka against 71.5 and $90 \%$ in the peasant plantation. Samples from the peasant zone were therefore the most sensitive to this extract. The synthetic fungicide induced an inhibition of conidial germination up to $99 \%$ in the peasant zone and 38.6\% in Mussaka. The bankit was less effective than the $\mathrm{C}_{3}$ concentration with samples from the Mussaka industrial plantation (P $<0.05)$. Conidia from the industrial plantation of Njombe (PHP), showed resistance to AqE. The percentages of inhibition obtained were very low, 10.1, 16.2 and $17.7 \%$ respectively at doses $\mathrm{C}_{1}, \mathrm{C}_{2}$ and $\mathrm{C}_{3}$ (Table 3). 


\section{Macrothink}

Journal of Agricultural Studies

ISSN 2166-0379

2021, Vol. 9, No. 2

Table 3. Effect of the various extracts and azoxystrobin on the germination of M. fijiensis conidia

\begin{tabular}{|c|c|c|c|c|}
\hline & 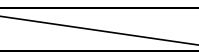 & PHP & MUSSAKA & PEASANT \\
\hline \multirow{5}{*}{$\mathrm{HE}$} & $\mathrm{T}$ & $0.00 \pm 0$ & $0.00 \pm 0$ & $0.00 \pm 0$ \\
\hline & $\mathrm{C}_{1}$ & $0 \mathrm{a} \pm 0$ & $0.2 \mathrm{a} \pm 0.1$ & $-0.1 \mathrm{a} \pm 0.0$ \\
\hline & $\mathrm{C}_{2}$ & $0.5 \mathrm{a} \pm 0.3$ & $0.1 \mathrm{a} \pm 0$ & $0.5 b \pm 0.4$ \\
\hline & $\mathrm{C}_{3}$ & $0 \mathrm{a} \pm 0$ & $0.6 \mathrm{a} \pm 0.5$ & $8.6 b \pm 2$ \\
\hline & $\mathrm{T}+$ & $85 b \pm 9$ & $38.6 \mathrm{~b} \pm 7.9$ & $99.5 c \pm 0.3$ \\
\hline \multirow{5}{*}{$\mathrm{AE}$} & $\mathrm{T}$ & $0.00 \pm 0$ & $0.00 \pm 0$ & $0.00 \pm 0$ \\
\hline & $\mathrm{C}_{1}$ & $2.5 \mathrm{a} \pm 2.2$ & $0.2 \mathrm{a} \pm 0.1$ & $7 \mathrm{a} \pm 1$ \\
\hline & $\mathrm{C}_{2}$ & $2.5 \mathrm{a} \pm 1.3$ & $2.5 \mathrm{a} \pm 1.5$ & $10 \mathrm{~b} \pm 2.5$ \\
\hline & $\mathrm{C}_{3}$ & $1 \mathrm{a} \pm 0.9$ & $3.2 \mathrm{~b} \pm 1.5$ & $24.2 c \pm 3.5$ \\
\hline & $\mathrm{T}+$ & $85 \mathrm{~b} \pm 9$ & $38.6 \mathrm{c} \pm 7.9$ & $99.5 \mathrm{~d} \pm 0.3$ \\
\hline \multirow{5}{*}{$\mathrm{AcE}$} & $\mathrm{T}$ & $0.00 \pm 0$ & $0.00 \pm 0$ & $0.00 \pm 0$ \\
\hline & $\mathrm{C}_{1}$ & $8.1 \mathrm{a} \pm 7.9$ & $38.5 \mathrm{a} \pm 7.1$ & $54.8 \mathrm{a} \pm 5.4$ \\
\hline & $\mathrm{C}_{2}$ & $64.1 \mathrm{~b} \pm 4.7$ & $85.4 \mathrm{~b} \pm 3.1$ & $97.8 \mathrm{~b} \pm 0.8$ \\
\hline & $\mathrm{C}_{3}$ & $99 \mathrm{~d} \pm 4.3$ & $96 \mathrm{c} \pm 1.4$ & $100 \mathrm{~b} \pm 0.0$ \\
\hline & $\mathrm{T}+$ & $85 \mathrm{c} \pm 9$ & $38.6 \mathrm{a} \pm 7.9$ & $99.5 b \pm 0.3$ \\
\hline \multirow{5}{*}{ ME } & $\mathrm{T}$ & $0.00 \pm 0$ & $0,00 \pm 0$ & $0.00 \pm 0$ \\
\hline & $\mathrm{C}_{1}$ & $17.8 \mathrm{a} \pm 6.5$ & $0 \mathrm{a} \pm 0.0$ & $13.4 \mathrm{a} \pm 5.7$ \\
\hline & $\mathrm{C}_{2}$ & $11.6 \mathrm{a} \pm 8.3$ & $0.6 \mathrm{a} \pm 0.5$ & $7.5 \mathrm{a} \pm 3.2$ \\
\hline & $\mathrm{C}_{3}$ & $34.8 \mathrm{~b} \pm 8.1$ & $34.6 \mathrm{~b} \pm 4.4$ & $9.1 \mathrm{a} \pm 3.3$ \\
\hline & $\mathrm{T}+$ & $85 \mathrm{c} \pm 9$ & $38.6 \mathrm{c} \pm 7.9$ & $99.5 b \pm 0.3$ \\
\hline \multirow{5}{*}{$\mathrm{AqE}$} & $\mathrm{T}$ & $0.00 \pm 0$ & $0.00 \pm 0$ & $0.00 \pm 0$ \\
\hline & $\mathrm{C}_{1}$ & $10.1 \mathrm{a} \pm 3.5$ & $9 \mathrm{a} \pm 4.3$ & $80 \mathrm{~b} \pm 4.3$ \\
\hline & $\mathrm{C}_{2}$ & $16.2 b \pm 7.5$ & $42.3 b \pm 3.6$ & $71.5 \mathrm{a} \pm 4.9$ \\
\hline & $\mathrm{C}_{3}$ & $17.7 b \pm 7.5$ & $62 \mathrm{c} \pm 4.6$ & $90 c \pm 2.3$ \\
\hline & $\mathrm{T}+$ & $85 c \pm 9$ & $38.6 \pm 7.9$ & $99.5 c \pm 0.3$ \\
\hline
\end{tabular}

For each site and each extract, the values assigned to the same letter do not differ significantly at the $5 \%$ threshold according to the Duncan test.a) $\mathrm{T}-: 0 \mathrm{mg} / \mathrm{ml}$; b) $\mathrm{C}_{1}: 6,25$ $\mathrm{mg} / \mathrm{ml}$; c) $\mathrm{C}_{2}: 12,5 \mathrm{mg} / \mathrm{ml}$; d) $\mathrm{C}_{3}: 25 \mathrm{mg} / \mathrm{ml} ; \mathrm{T}+: 10 \mathrm{ppm}$

The $56.28 \%$ probability threshold correlation circle revealed the existence of three distinct groups in the efficiency of the extracts in the inhibition of $M$. fijiensis conidia germination. A group consisting of HE which was ineffective, another group consisting of effective extracts, $\mathrm{AcE}, \mathrm{AqE}$ and $\mathrm{T}+$, and a last group for the extracts with low efficiency, ME and EAE (Fig. 12). 


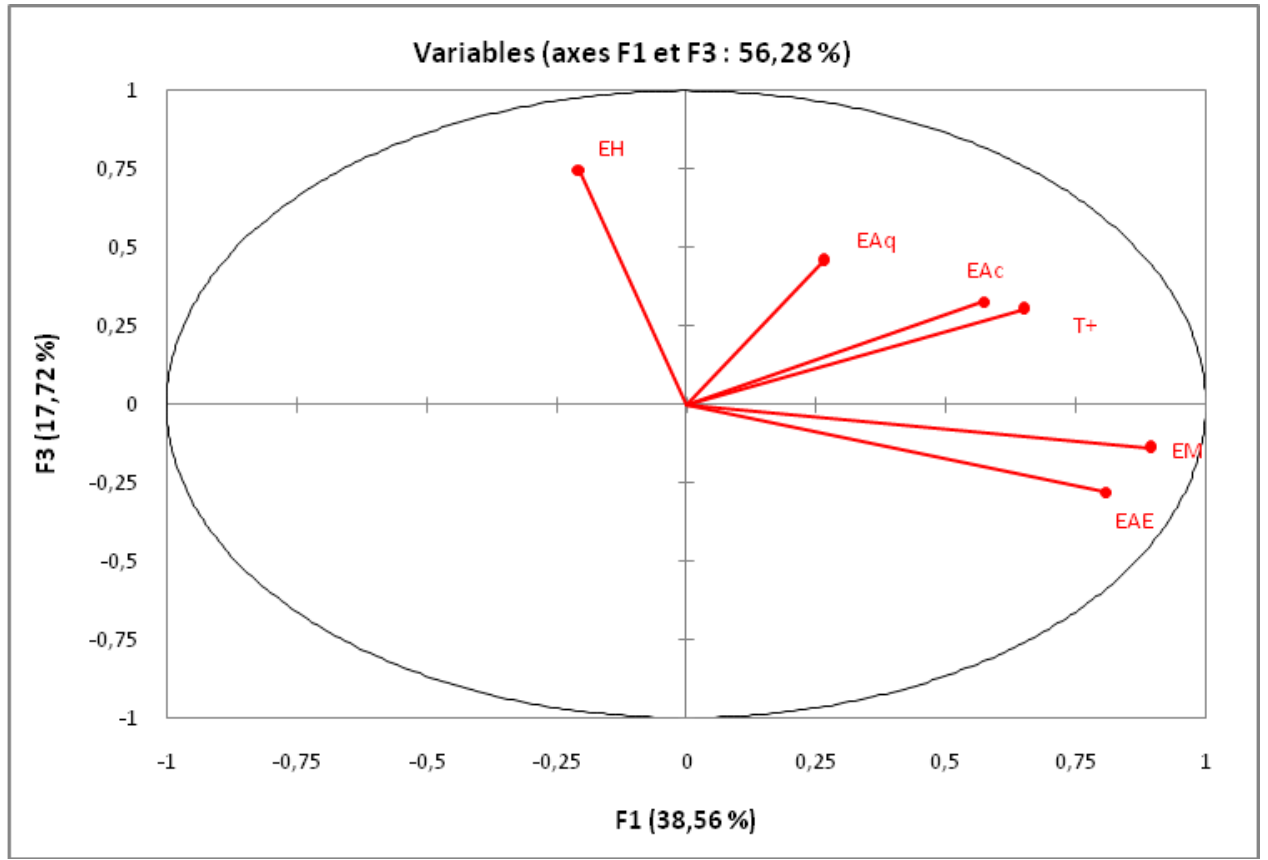

Figure 12. Mapping extracts and fungicide effective on the inhibition of conidial germination of $M$. fijiensis

4. Minimal Inhibitory Concentrations $\mathrm{MIC}_{50}$ and $\mathrm{MIC}_{90}$ of germ tube growth of $M$. fijiensis strains

The lowest MICs were obtained with AcE and AqE. MIC 50 ranges from $2.0 \mu \mathrm{l} / \mathrm{ml}$ to $3.3 \mu \mathrm{l} / \mathrm{ml}$ for AcE and from $6.0 \mathrm{mg} / \mathrm{ml}$ to $15.0 \mathrm{mg} / \mathrm{ml}$ for AqE. The highest MICs were obtained with HE. Thus, with EAE, the $\mathrm{MIC}_{50}$ values varied from 20.1 to $30 \mu \mathrm{l} / \mathrm{ml}$ respectively for Mussaka and Njombe (PHP) and with the ME from 27.1 to $403.4 \mu \mathrm{l} / \mathrm{ml}$. However, the $\mathrm{MIC}_{\mathbf{5 0}}$ and $\mathrm{MIC}_{90}$ of AcE were substantially equal in all the zones (3.3, 2.0 and $3.3 \mu \mathrm{l} / \mathrm{ml}$ ) which indicates the same behavior of the extract with respect to all strains regardless of the sampling site (Table 4). 
Table 4. $\mathrm{CMI}_{50}$ and $\mathrm{CMI}_{90}$ of the growth of the germ tube of $M$. fijiensis with the different extracts tested $(\mu \mathrm{l} / \mathrm{ml}$ or $\mathrm{mg} / \mathrm{ml})$

\begin{tabular}{lccccccccccc}
\hline & \multicolumn{10}{c}{ Treatment } \\
\cline { 2 - 12 } Sites & HE & \multicolumn{1}{c}{ EAE } & \multicolumn{1}{c}{ AcE } & ME & \multicolumn{1}{c}{ AqE } & \\
& CMI $_{50}$ & $\mathrm{CMI}_{90}$ & $\mathrm{CMI}_{50}$ & $\mathrm{CMI}_{90}$ & $\mathrm{CMI}_{50}$ & $\mathrm{CMI}_{90}$ & $\mathrm{CMI}_{50}$ & $\mathrm{CMI}_{90}$ & $\mathrm{CMI}_{50}$ & $\mathrm{CMI}_{90}$ \\
\hline PHP & $*$ & & 30,0 & 167,2 & $\mathbf{3 , 3}$ & $\mathbf{1 4 , 7}$ & $*$ & $*$ & & 15,0 & 525,1 \\
MUSSAKA & $*$ & 20,1 & 73,4 & $\mathbf{2 , 0}$ & $\mathbf{1 8 , 0}$ & 27,1 & 74,7 & 6,0 & 40,1 \\
PEASANT & 5431 & $1,210^{6}$ & 24,5 & 97,7 & $\mathbf{3 , 0}$ & $\mathbf{1 8 , 0}$ & 403,4 & 1066 & $*$ & 369,2 \\
\hline
\end{tabular}

*values no founded (negative correlations)

\section{Discussion}

The present study was based on the extraction of natural substances from the seeds of $T$. peruviana and on the evaluation of the antifungal potential of its extracts on $M$. fijiensis, responsible for the disease of black streaks of banana.

The chromatographic of The AcE has showed many major compounds, its effectiveness could be due to the presence of molecules that act in high doses. Gata-Goncalves et al. (2003) also showed after GC-MS of extract of T. peruviana, presence of many compounds

Plant extracts have already shown their effectiveness against the germination of fungal spores. This is the case with the results of Achraf et al. (2012) which found out that the aqueous extract of Asphodelus tenuifolius and Zygophyllum albumwere effective in inhibiting spore germination of Penicillum expansum with a percentage inhibition of $95.48 \%$ and $93.82 \%$. The ethanol extracts of the leaves of $O$. gratissimum and Aframomum melegueta prevent the spores of Fusarium oxysporum and Aspergillus niger from germinating by more than 65\%, according to the findings of Okigbo \& Ogbonnaya (2006).

The AcE greatly reduced the germ tube elongation of $M$. fijiensis strains, followed by EAq. The AcE was very effective in inhibiting the germination of $M$. fijiensis strains in all banana growing areas studied, being more effective than the chemical fungicide azoxystrobin used. It inhibited more than $90 \%$ conidial germination. These results are similar to those of Arciniegas, (2002) and Arciniegas et al. (2002) who showed an in vitro test a strong antifungal activity on both colony development and germination of $M$. fijiensis conidia using crude ethanol extracts, amphipolar solvent as well as acetone extract of eight plants such as Commelina diffusa, Momordica charantia, Piper hispidum, Piper peltatum, Sida rhombifolia and Syzyrgium aromatica.

Furthermore, Paola (2006) obtained a significant reduction in the incidence and severity of black leaf streak disease on plants infected artificially with $M$. fijiensis conidia after being treated with extracts obtained from the maceration of Momordica charantia and Senna reticulata in water/alcohol mixture. Indeed, the phytochemical analysis performed on $S$. reticulata with which they obtained the best results revealed the presence of a variety of 
secondary metabolites such as polyphenols, coumarins, saponins, triterpenes, flavonoids some of which are found in the extract with acetone (AcE) from $T$. peruviana (Gata-Goncalves et al., 2003; Ngoh Dooh et al., 2014). These extracts are known for their antifungal activity or resistance to the induction on $M$. fijiensis (Riveros et al., 2003; Polanco, 2004).

The growth and germination rates obtained with HE, EAE and ME were significantly higher (77.9\% to $92.3 \%$ ) at the reported Strobilurin resistance threshold which shows the resistance of the strains of these zones to these extracts. Only the $\mathrm{C}_{3}$ doses of EAE and EAq gave lower rates with Mussaka strains. The growth and germination rates obtained for the EAq at doses $\mathrm{C}_{1}, \mathrm{C}_{2}$ and $\mathrm{C}_{3}$, despite the effectiveness of this extract did not fall below the resistance threshold of Strobilurins. The growth and germination rates achieved with EAc were below the Strobilurin resistance level at $\mathrm{C}_{2}$ and $\mathrm{C}_{3}$ on growth and in all areas at $\mathrm{C}_{2}$ and $\mathrm{C}_{3}$ with Mbome and Mussaka strains and the $\mathrm{C}_{3}$ dose at the PHP, on the germination, which shows the sensitivity of the strains of these zones to this extract.

With the bankit, the growth level of the germ tube was below the strobilurin resistance threshold in two of the three study areas (Hermento et al., 2010). The lowest rate was obtained in the plantation, $7.6 \%$, followed by the Njombe industrial plantation. An onset of resistance was obtained in Mussaka with azoxystrobin (49.6\%).

The bankit whose active ingredient, azoxystrobin, was used in this study was found to be effective in some production areas compared to others. Azoxystrobin, which belongs to the Strobilurins class, is a potent inhibitor of cell respiration, hence its effectiveness against germ tube elongation and germination (both parameters being linked). This result corroborates that of Essis et al. (2010) who obtained an efficacy in the laboratory of azoxystrobin against the germ tube growth of $M$. fijiensis strains from Ivory Coast banana plantations. However, in Mussaka a resistance to this fungicide was detected. This could be explained by the abusive use of this compound which eventually developed resistant strains compared to the peasant zone where there is no use of the bankit. This result is contrary to that of Nguepjop (2011) which indicated a lack of resistant strains in this zone. Ngando et al. (2006) showed resistance phenomena in banana plantations in Cameroon. The low efficiency of azoxystrobin in the peasant plantation denotes the appearance of resistant strains, despite the distance with the industrial zones. This could be explained by the movement of men from one corner to another and who would carry conidia resistant strains to areas where they do not exist (peasant zone).

The $\mathrm{MIC}_{50}$ of the different extracts were determined with the different strains tested. Low variability was observed. The low values and close to the MICs obtained with the acetone extract demonstrate the efficacy and fungicidal properties of this extract in inhibiting the germination of the conidia of the fungus tested. These results are in agreement with those of Doumbouya et al. (2012) who showed that the low MIC values of Ocimum graticimum extracts inhibit the development of phytopathogenic fungi.

The inhibition percentages obtained were different according to the extracts. This can be explain by the process of obtention the extracts. Okigbo (2005) showed that the levels of 
bioactive compounds in plants with antifungal activity could be influenced by many factors, including the plant's age, harvest time, extraction solvent, and method of extraction. Indeed, for the same species of fungi, an extract preceding or following another could show an effectiveness contrary to its predecessor or its successor. Thus, AcE was effective in inhibiting the germination of all strains studied, unlike methanol which showed no efficacy meanwhile these two solvents are polar. The extraction with acetone would have taken the active ingredient acting on the germination before the application of methanol.

The plant used in this study belongs to the Apocynaceae family. The extracts contain many chemical compounds. These compounds could act on the target organisms in several ways. They could inhibit growth by acting on metabolic functions such as cell division. Others would inhibit respiration by blocking ATP production or inducing plant resistance (Laurent et al., 2003; Lepoivre 2003; Chwaleka et al., 2006).

\section{Conclusion}

The AcE and AqE were effective as azoxystrobin, the active ingredient in the bankit, a fungicide commonly used against growth tube length and germination of conidia of $M$. fijiensis responsible of black leaf streak disease. The GC-MS revealed many compounds with antifungal properties.

\section{Acknowledgement}

Our thanks to the Director of CARBAP (Plantain Banana Research Center) of Africa, Dr. Ngando Essoh and the entire team (technicians) of the CARBAP Phytopathology Laboratory (Mpouli, Nguidjo, Dongmo) with who the sampling in field was done and Dr. Amayana, Former Scientific Director of the IRAD of Ekona in South West Cameroon.

\section{References}

Abadie, C., Peyraachon T., \& Fouré E. (1999). Lutte intégrée contre la maladie des raies noires des bananiers et plantains au Cameroun. Développement d'un système d'avertissement agricole. Biosciences proceedings, 6, 22-31.

Achraf, K., Boumediene, M., Abdllah, M., Houcine, B., \& Saif, G. (2012). Phytochemical and in vitro Antifungal Effect of some Plants Extract of Asphodelus Tenuifolius Cavanand Zygophyllum Album L.on Fungi Development. European Journal of Scientific Research, 80(3), 311-321.

Ambang, Z., Ndongo, B., Essono, G., NgohDooh, J. P., Kosma, P., Chewachong, G.M., \& Asanga A. (2011). Control of leaf spot disease caused by Cercosporasp on groundnut (Arachishypogeae) using methanolic extracts of yellow oleander (Thevetiaperuviana) seeds. Australasian Journal of Crop Science, 5(3), 227-232. ISSN:1835-2707

Ambang, Z., Ndongo, B., Ngoh Dooh, J. P., \& Djilé, B. (2005). Effet des extraits de graines de laurier jaune (Thevetia peruviana (Pers) K. Schum sur les charançons (Sitophilus zeamais Motsch) ravageurs des stocks. Biosciences proceedings, 11, 57-83. ISSN 1019-7702

Arciniegas, A. (2002). Evaluaciondelpotentialantifungico de 20 extractos de 
plantasassociadas a MusásobreMycosphaerellafijiensis. Trabajo de grado (TituloBilògo). Bibliotleca Rafael Parra Cortés Universidaddel Tolima Facultad de Ciencias, 155 p.

Arciniegas, A., Riveros, A. S., \& Loaiza J. (2002). Efecto de extractovégetables Sobre el desarrolloin vitro de M. fijiensis, agente causale de la Sigatokanegra en MusáCeas. En: XV ReunionInternacionalAcorbat-Augura Colombia. (27 oct-2nov) Cartagena, Colombia 242 p.

Bautista-Banos, S., Hernandez-Lopez M. \& Barrera-Neecha L. L. (2000). Antifungal screening of plants of the state of Morelos, Mexico, against four postharvest pathogens of fruits and vegetables. Mexican Journal of Phytopathology, 18, 36-41.

Brent, K. J., \& Hollomon D. W. (1998). Fungicide resistance the assessment of risk, FRAC. Global Crop Protection Federation, 2, 1-48.

Churchill, A. C. L. (2011). Mycosphaerella fijiensis, the black leaf streak pathogen of banana: progress towards understanding biology and detection, disease development, and the challenges of control. MolecularPlant pathology 12(4), 307-329. https://doi.org/10.1111/j.1364-3703.2010.00672.x

Chwaleka, M., Lalunb, N., Bobichonc, H., Plea, K., \& Voutquenne-Azabadiokoa L. (2006). Structure-activity relationships of some hederagenindiglycosides: Haemolysis, cytotoxicity and apoptosis induction. BiochimicaetBiophysicaActa, 1760, 1418-1427. https://doi.org/10.1016/j.bbagen.2006.05.004

De Lapeyre de Bellaire, L., Fouré, E., Abadie, C., \& Carlier, J. (2010). Black leaf steak disease is challenging the banana industrie. Fruits, 65(6), 1-21. https://doi.org/10.1051/fruits/2010034

De Lapeyre de Bellaire, L., Ngando, E. J., Abadie, C., Chabrier C., Blanco R., Lescot T., Carlier J., \& Cote F. (2009). Is chemical control of Mycosphaerella foliar diseases of bananas sustainable? Acta Hortic, 828, 161-170. https://doi.org/10.17660/ActaHortic.2009.828.16

Dohou, N., Yamni, K., Badoc, A., \& Douira, A. (2004). Activité antifongique d'extraits de Thymelaealythroidessur trois champignons pathogènes du riz. Bull. Soc. Pharm. Bordeaux. 143, 31-38.

Doumbouya, M., Abo, K., Lepengue, H.N., Camara, B., Kanko, K., Aidara, D., \& Kone, D. (2012). Activités comparées in vitro de deux fongicides de synthèse et de deux huiles essentielles sur les les champignons telluriques des cultures maraichères en Côte d'Ivoire. Journal of Applied Biosciences, 50, 3520-3532.

Du Pont, L.A. (1983). Black and yellow sigatoka. Improved identification and management techniques. Coral Gables (US). In: EPPO Bulletin, 21, 291-354.

El Guilli, M., Achbani, E., Fahad, K., \& Jijakli, H. (2009). Biopesticides: Alternatives à la lutte chimique In: Agriculture durable en region méditerranéenne (AGDUMED); rabat, Maroc. 266-280.

El Hadrami, A. (2000). Caractérisation de la résistance partielle des bananiers à la maladie 
des raies noires et évaluation de la variabilité de l'agressivité de l'agent causal, Mycosphaerellafijiensis. Thèse de Doctorat, Faculté des Sciences Agronomiques Gembloux $153 \mathrm{p}$.

Essis, B., Kobenan, K., Traore, S., Kone, D., \& Yatti, J. (2010). Sensibilité au laboratoire de Mycosphaerellafijiensis responsable de la cercosporiose noire des bananiers vis-à-vis de fongicides couramment utilisés dans les bananerais ivoiriennes. Journal of Animal and Plant Sciences, 7(2), 822833.

Fouré, E., \& Moreau, A. (1992). Contribution à l'étude épidémiologique de la cercosporiose noire dans la zone bananière du Moungo au Cameroun de 1987 à 1989. Fruits 47(1), 3-16.

Fullerton, R. A. (1994). Sigatoka leaf disease. In :Ploetz R.C., Zentmyer G., Nishijima W.T., Rohrbach K.G., Ohr H.D. (eds.). Compendium of Tropical Fruit Disease, 11, 12-13.

Gata-Gonçalvès, L.(2001). Proprieda des biocides de plantas de Origem Tropical: caso da Thevetia peruviana Schum. $\mathrm{Ph} \mathrm{D}$ Thesis. Engenharia AgronomicaQuinima. Campo das CebolasLisboa.133 p.

Gata-Gonçalvès, L., Nogueira, J.M.F., Matos, O., \& Bruno De Sousa. (2003). Phytoactive extract from Thevetia peruviana with antifunal properties agains Cladosporuim cucumerinum. Journal of photochimistry and photobiology, 70(1), 51-54. https://doi.org/10.1016/S1011-1344(03)00024-1

Hermento, C., Opina S.O., \& Natural P.M. (2010). Assessment of fungicide resistance of a population of Mycosphaerella spp. On senorita banana variety (Sucrier Group). Tree and Forestry Science and Biotechnology, 4(2), 85-91.

Jacome, L. H., \& Schuh, W. (1992). Effects of leaf wetness and temperature on development of black sigatoka disease on banana infected by Mycosphaerella fijiensis var. difformis. Phytopathology, 82, 515-520. https://doi.org/10.1094/Phyto-82-515

Jones, D. (2009). Disease and pest constraints to banana production. Acta. Hortic., 828, 21-36. https://doi.org/10.17660/ActaHortic.2009.828.1

Kassi, F. M., Badou, O. J., Tonzibo, Z. F., Salah, Z., Amari, L. N. D. G. E., \& Kone D. (2014). Action $\mathrm{du}$ fongicide naturel NECO contre la cercosporiose noire (Mycosphaerella fijiensisMorelet) chez le bananier plantain (AAB) en Côte d'Ivoire. Journal of Applied Biosciences, 75, 6183-6191. https://doi.org/10.4314/jab.v75i1.3

Knight, S., Wirz, M., Amil, A., Hall, A., \& Shaw M. (2002). The role of managing resistance to fungicide in maintaining strategies to control black leaf streak disease. In L. Jacome, P. Lepoivre, D. Marin, R. Ortiz, R. Romero and J.V. Escalent (Eds.). Mycosphaerella leaf spot diseases of bananas: present status and outlook. Proceedings of the $2^{\text {nd }}$ International workshop on Mycosphaerella leaf spot diseases, San José Costa Rica, 303-307 p.

Lassoudière, A. (2010). L'histoire du bananier. Quae, Paris, 416 p.

Laurent, P., Dooms, C., Braekman, J.C., Daloze, D., Habibjiwan, J. L., Rozenberg, A., ... 
Pasteels, J. M. (2003). Oleamane glycosides in defensive glands of Chrysomelid beetles are produced from dietary B-amyrin. Naturwissenschaften, 90, 524-527. https://doi.org/10.1007/s00114-003-0471-y

Lepoivre, P. (2003). Phytopathologie: bases moléculaires et biologiques des pathosystèmes et fondements des stratégies de lutte. Les presses agronomiques de Gembloux. pp. 289-317.

Leroux, P., Gredt, M., \& Fritz, R. (1978). Etudes en laboratoire des souches de quelques champignons phytopathogènes résistantes à la dichlozoline, à la dicyclidine, à l'iprodione, à la vinchlozoline et à divers fongicides aromatiques. Med. Fac. Landboww Rijksunia Gent, 43, 881-889.

Lescot, T. (2006). La banane en chiffres: le fruit préféré de la planète. Fruitrop, 140, 1-5.

Marin, D. H., Romeiro, R. A., Guzman, M., \& Sutton, T. B. (2003). Black Sigatoka: an increasing threat to banana cultivation. Plant Disease, 87, 208-222. https://doi.org/10.1094/PDIS.2003.87.3.208

Mouliom-Pefoura, A., Lassoudiere, A., Foko, J., \& Fontem D.A. (1996). Comparison on development of Mycosphaerellafijiensis and Mycosphaerellamusicola on banana and plantain in the various ecological zones in Cameroun. Plant Dis., 80(8), 950-954. https://doi.org/10.1094/PD-80-0950

Mourichon, X. (2003). Analyse des risques phytosanitaires: appui à la rédaction de la réglementation scientifique au Département d'Outre-mer. Cirad, Montpellier, 32 p.

Negrette, R., Backhouse, N., \& Bravo B. (1987). Quelques flavonoides de Centaurée flocosa. Plantes médicinales et phytothérapie, 21(2), 168-172.

Ngando E. O. J., Rieux, A., Nguidjo, O., Pignolet, L., Dubois, C., Mehl, A., Zapater, M-F., Carlier, J., and De Lapeyre de Bellaire L. (2015). A novel bioassay to monitor fungicide sensitivity in Mycosphaerellafijiensis. Pest Management Science, 71(3), 441-451. https://doi.org/10.1002/ps.3825

Ngando, E.J., De Lapeyre, De B. L., \& Fouré E. (2006). La lutte chmique raisonnée contre la maladie des raies noires au Cameroun: évolution de la résistance aux fongicides. In $8^{\mathrm{e}}$ conférence internationale sur les maladies des plantes industrielle, AFPP, Tours, pp. 633-642.

Ngoh Dooh, J. P, Ambang, Z, Tih, Ewola A, Heu, A., Kosma, P., MahoYalen, E. J., \& Ghogomu, T. R., (2014a). Screening and the effect of extracts of Thevetiaperuviana on the development of Colletotrichumgloeosporioides, causal agent of cassava anthracnose disease. E3 Journal of Agricultural Research and Development, 4(4), 054-065. ISSN: 2276-9897

Ngoh Dooh, J.P., Ambang, Z., Ndongo, B., Heu, A., Kuate, T. W.N. (2014b). Effect of extracts of Thevetia peruviana (Pers.) K. Schum on development of Phytophthora megakarya causal agent of black pod disease of cocoa. Journal of Applied Biosciences, 77, 6564-6574. ISSN 1997-5902. https://doi.org/10.4314/jab.v77i1.11

Ngoh Dooh, J.P., Ambang, Z., Ndongo, B., Kuate, T.W.N., Heu, A., \& Ntsomboh Ntsefong G. 
(2015). Development of Cocoa Black Pod Disease (Caused by Phytophthora megakarya) in Cameroon when Treated with Extracts of Thevetia peruviana or Ridomil, Int. J. Curr. Res. Biosci. Plant Biol., 2(3), 47-59. ISSN 2349-8080

Nguepjop, J.R. (2011). Comparaison de deux méthodes de mesures de la résistance aux fongicides systémiques chez Mycosphaerella fijiensisMorelet. Mémoire de Master II, Université de Yaoundé I, 42 p.

Oji, O., \& Okafor. Q. E. (2000). Toxicological studies on steam bark, leaf and seed kernel of Yellow Oleander (Thevethiaperuviana). Phytother. Res., 14, 133-135. https://doi.org/10.1002/(SICI)1099-1573(200003)14:2<133::AID-PTR598>3.0.CO;2-K

Okigbo R. N., \& Ogbonnaya U. O. (2006). Antifungal effects of two tropical plant leaf extracts (Ocimum gratissimum and Aframomum melegueta) on postharvest yam (Dioscorea spp.) rot. African Journal of Biotechnology, 5(9), 727-731.

Okigbo, R. N. (2005). Biological control of postharvest fungal rot of yam (Dioscorea spp.) $\begin{array}{llll}\text { with } \quad \text { Bacillus } \quad \text { Subtilis. } & \text { Mycopathologia, }\end{array}$ https://doi.org/10.1007/s11046-004-2454-8

Paola, G. O. S. (2006). Evaluacion de hongosendofiticos y extractos botanicos para el control de la sigatoganegra (Mycosphaerella fijiensis Morelet) enbanano. Tesissometidae a consideracion de la escuelaposgrado, programa de educacion para el desarrollo y la conservacion del CATIE, $90 \mathrm{p}$.

Polanco, D. (2004). Validación del potencial antifúngico de extractos de plantas sobre Mycosphaerella fijiensis, agente causal de la Sigatokanegra, en el cultivo de banano. M.Sc. CienciasBiológicas. Biblioteca Rafael Parra Cortés. Universidaddel Tolima, Ibagué, Colombia. $138 \mathrm{p}$.

Reed, D. K., Freedman, B., \& Ladd, T. L. (1982). Insecticidal and antifeedant activity of neriifolin against Codling moth, Striped cucumber beetle and Japanese beetle. J. Econ. Entomol., 75(6), 1093-1097. https://doi.org/10.1093/jee/75.6.1093

Riveros, A. S., Giraldo, C. I., \& Gamboa, A. (2003). Microbiological control of black leaf streak disease. In: Jacome et al. (eds.). Microsphaerella leaf spot diseases of banana: present status and outlook. Proceedings of the workshop on Mycosphaerella leaf spot diseases. San Josue (CRI), Montpellier (FRA): Inibap, 317 p.

Saxena, V. K., \& Jain, S. K. (1990). Thevetia peruviana kernel oil: a potential Bactericidal agent. Fitoterapia, 61, 348-349,

Smith, C. M., Trivellas, A. E., Johnson, L. E. B., \& Joshi M. M. (1991). Methods for monitoring the sensitivity of a range of fungal pathogens to benzimidazole fungicides. EPPO Bulletin, 21, 332-335. https://doi.org/10.1111/j.1365-2338.1991.tb01260.x

Stoll, G. Protection Naturelle des Végétaux en Zone Tropicale. CTA. AGRECO. pp. 95-99

Stover, R. H. (1980). Sigatoka leaf spot of banana and plantains. Plant disease, 
64(8), 750-756. https://doi.org/10.1094/PD-64-750

Tewtrakul, S, Nakamura, N, Hattori, M, Fugiwara, T., \& Suparita T. (2002). Flavonone and flavonol glycosides from leaves of ThevetiaperuvianaAnd their HIV-1 reverse transcriptase and HIV-1 integrase Inhibitory activities. Chem. Pharm. Bull., 50, 630-635. https://doi.org/10.1248/cpb.50.630

\section{Copyright Disclaimer}

Copyright for this article is retained by the author(s), with first publication rights granted to the journal.

This is an open-access article distributed under the terms and conditions of the Creative Commons Attribution license (http://creativecommons.org/licenses/by/4.0/). 